\title{
Wife beating amongst Africans as a challenge to pastoral care
}

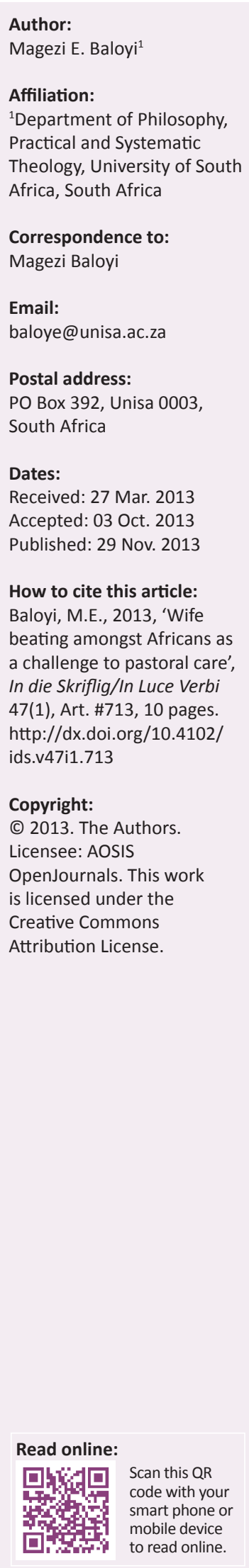

Traditional African people are known for respecting their marriage. Even though marriage is so highly regarded, it is astonishing to realise that wife beating has become an extremely common practice amongst them. It therefore becomes an important research question to ask about the extent to which deeply-seated traditional customs regarding wife beating as a form of stamping down authority and of trying to keep the household in order, will have to be confronted with what is deemed to be good practice from the perspective of the law, community and pastoral caregivers. There are women who live with scars on their faces and bodies, having been beaten by their husbands. Although there are many forms of abuse towards women in family situations, this article aims particularly to focus on wife beating that is practiced for traditional as well as other related reasons. This research will involve itself with establishing whether the reasons for wife beating are part of the traditional system for keeping the household in order and interrogate both legal and pastoral interventions that attempt to eliminate or avoid such behaviour.

Vroueslanery onder Afrikane as 'n uitdaging vir pastorale sorg. Tradisionele Afrikane is nog altyd daarvoor bekend dat hulle die instelling van die huwelik respekteer. Verbasend genoeg is vroueslanery egter 'n ou gevestigde gebruik wat vandag algemeen onder Afrikane voorkom. Die mate waartoe diepgewortelde gebruike soos vroueslanery as ' $n$ manier om gesag af te dwing en orde in die huis te handhaaf, gekonfronteer sal moet word met wat as goeie praktyk beskou word vanuit die gesigspunt van die reg, die gemeenskap en pastorale versorgers, is dus 'n belangrike navorsingsvraag. Baie vroue dra fisiese en emosionele littekens wat deur hulle eggenote veroorsaak is. Alhoewel daar baie vorme van vrouemishandeling in familiesituasies voorkom, fokus hierdie artikel veral op vroueslanery wat om tradisionele en verwante redes beoefen word. Hierdie navorsing probeer vasstel of die redes vir vroueslanery deel van die tradisionele sisteem uitmaak waarvolgens orde in die huishouding gehandhaaf is. Dit ondersoek regs- sowel as pastorale ingryping wat sodanige gedrag probeer elimineer of voorkom.

\section{Introduction}

Despite its horrible consequences, the practice of wife beating has become an accepted way of keeping wives under control amongst some traditional African people. Fidgen (2009:1) pictures this sad state of affairs in the following way: 'The majority of women enjoy a beating, because they are made to believe it is part of our tradition.' According to Maluleke and Nadar (2002:10), the beating received by one such woman, Nkhensani (fictitious name), did not only land her in hospital, but she also attempted suicide as a result. It is not only sad to see that, despite our constitution talking about respecting each other's human rights, the battering and beating of women remain a huge challenge - a challenge that has seen many marriages dissolved in divorce courts and has left many women permanently scarred both physically and mentally. Battered women also experience many emotional and psychological problems. This is what led Phoofolo (2007:372) to argue that wife battering sets in motion a chain of events starting with women deserting their husbands and ending in applications to formally divorce them. One abused woman who is a primary school teacher in a village outside Malamulele Township (Limpopo) and preferred to remain anonymous, told the author (on 22 February 2008) in an interview:

'Whenever I realized his voice as that of a drunk man from the cellphone, I start preparing myself to go and sleep in one of the neighbor's house. There was a day when he was knocking in the front door I jumped through the window and slept just behind the house. But when I woke up in the morning I realized that he also slept out behind the same house in a different corner because he failed to open the door. I cannot remember how many times I went home and he kept on following me because of his beating habit.' (Anonymous)

This statement is an indication that, in some cases, wife beating is practiced in families of educated people too. 
The above mentioned woman's husband is also a teacher at the local high school and he is so used to beating his wife that it reached the point where everyone in the village knew that his wife would be looking for an alternative place to sleep rather than sleeping at home. The wife's pastor tried to intervene in the past to calm the situation, but the husband accused him of being in love with his wife. The wife further said that she would never attempt to put burglar bars in their newly built house as it would close all her escape routes for those days when her husband comes home drunk.

In another case, the author was visited by another man (husband) who used to beat his wife in Malamulele Township. He boasted, saying:

'When she was pregnant with our second baby I enjoyed beating her until she bled. She knows if I start beating I will only stop when I see blood. One day as I was fetching my sjambok in the car, she escaped through the window and she went to her mother's home.' (Male, 45 years old)

A father of three who chose to be anonymous proudly said (on 07 June 2006) that he had beaten his wife until she decided to file for divorce which is still pending. This is similar to what Phoofolo (2007:372) found in his research when he referred to a woman who was beaten until she fled back to her father. She actually slept in the mountains, reaching her father's home three days later. She refused to return to her husband.

Ntombifuthi Zwane of Brits (Baloyi 2009a:139-140) was beaten so badly that she fled from the house naked. Because of the severe, continuous nature of the beating she received, she feared that she would be wasting time by fetching clothes.

In an article entitled 'Woman killed for going on the pill', Rampedi (2010:8) reported that two children were left without a mother after their mother, a farmworker (Nyika, aged 31) was beaten to death by her husband in Brits, near Pretoria, for having taken contraceptives. Although this research article does not focus on the killing of women, but on wife beating, it is important to see how the beating of wives impacts both children and community.

Baloyi (2009a:161) says: 'It has become a normal way of living to some husbands to beat their wives, whilst it has become a norm for women to accept such treatment with both hands.' Whilst no women like abuse, Bila (2003) points out in her research findings that some women do internalise being their husbands' punch bags and their husbands beat them with pride. The author of this article remembers an incident from the late 1990s when a fellow theological student and former schoolmate confessed beating his wife until she lost three of her teeth (Baloyi 2009a:160)

Hinga (in Waruta \& Kinoti 2000:139) said: 'In 1979 I witnessed a woman being beaten for not less than four hours, in the streets of Eastleigh in Nairobi.' It became worse when the crowd gathering to witness the beating, showed their obvious enjoyment of the spectacle and were actually cheering the man, claiming that 'she deserves it!' Some husbands beat their wives in front of their children to humiliate them and cover their wives with shame (Waruta \& Kinoti ibid:130).
Another shocking story emerges from the research of Dreyer (2009):

She told me about the last time she had suffered a serious attack: on the day before the Christmas Eve her husband had twisted her head around so violently that she thought she was going to die. (p. 12)

This quotation was taken from the subheading 'Narratives of violence against women' in which Dreyer interviewed a woman who was living under brutal attacks by her husband. Incidents like this clarify the fact that wife beating and other types of assaults have become very common amongst some married couples, and they really need pastoral intervention. It is said that, amongst the issues that were not considered before, some female political representatives also intervened to help battered women (Deegan 2009:108). The South African context indicates that wife beating is practiced by many people.

\section{The relevance and methodology of the study}

Baloyi (2009b) contends that the growing number of broken families and 'fatherless' children is sometimes the result of the abuse of women, including wife beating. Wife beating, like any other form of oppression or abuse towards women, does not only degrade women, but it also takes away their dignity and humiliates and traumatises them. Amongst other things, practical theology must deal with human problems in a particular context. From a specific vantage point, if theology is not contextual and faces the realities of people in their own situations, then theology is not only irrelevant, but has no reason to exist. That is why I strongly agree with Cone (1986:5) who argues: 'Theology must relate the message to the situation of the church's involvement in the world but not to retell the biblical story.' It is for the victimisation of these women that the 'God of the Oppressed', according to Cone (1986:2), must become the voice of the voiceless by also 'making right from what man [sic] made wrong.' Schleiermacher (in Burkhart 1983:189) is of the same opinion when he articulates that caregivers are challenged to be practical when dealing with issues of abuse and domination. In his book An introduction to pastoral care', Gerkin (1997:27) sees the caring leader as a shepherd. It is from this perspective that the author sees the relevance of this article. The fact that Jesus related to and socialised with drunkards, outcasts, prostitutes and thieves as a way to liberate and save them, should similarly be the intention of the church and pastoral involvement. They, too, should be out there helping and liberating women who are battered and beaten by their husbands. It is therefore the aim of this article to unveil and discuss how some African people have traditionalised and reasoned in favour of wife beating (Fidgen 2009:1). African sayings relevant to the topic will also be used to argue how the African tradition succeeded in internalising and even normalising this practice. This article will make use of case studies encountered by the author in his pastoral ministry and of relevant reading material such as newspapers, books and other sources to argue this point. The information gathered from the literature and case 
studies will be evaluated in the light of both the Bible and some aspects of liberation theology (e.g. Cone 1975; 1986) before concluding with possible pastoral guidelines. Some arguments by liberation theologians will be used against the practice of wife beating. The article intends to argue that it is not only the duty of government and other organisations to help liberate women from wife beating, but it is also the duty of the church through its pastoral services to support the oppressed in the same way that God too was on the side of the oppressed in Egypt (Cone 1975:63). Although the research is been done in a South African context the whole of Africa often has overlapping views. Therefore, in the course of the discussion, it will be important where necessary, to also view the problem in a broader African context.

\section{Causes or reasons often cited for wife beating Traditional reasons}

From a traditional point of view, many men think that wife beating is part of their marital rights and privileges. One example of this comes from an arrested man asked from his cell: 'I do not understand why I am arrested for beating my own wife' (Anon 2007:10). This comes from a traditional understanding which views the wife as a chattel along with other property belonging to the husband (Hinga et al. 2008:170). This view is also articulated by Waruta and Kinothi (2000:123) who say: 'Therefore the men own the women for they bought them, just like shoes, cars or other properties.' Many women, for their part, seem generally to be silent which may, in a sense, make their abusers (husbands) think that they accept their destiny even when they have done them actual bodily harm (Day 2013). The women, too, seem to assume that being battered, is part of the marriage package. This is evident from a survey conducted by female researchers on women's awareness of their rights (Waruta \& Kinoti ibid:140). There are various factors that can be labelled as traditional reasons for the beating, but a few selected arguments will be used below for the sake of space and the purpose of this article.

\section{A negative view of lobolo}

Lobolo (a custom by which the bridegroom's family makes a gift either in the form of cash or cattle shortly before marriage takes place), which is a good custom for Africans and which is practiced by almost all African tribes, has also been used by some as a motivation for beating their wives. Two of the reasons why lobolo is good for Africans are the following: firstly, it helps to avoid the vat-en-sit [Living together as husband and wife without being officially married] marriages which are problematic and not approved by many Africans (Baloyi 2001:51). Secondly, relationships and communal life is strengthened during the practice (Baloyi 2010b:55). To substantiate this, I quote from the argument of a certain man who motivated the beating of his wife in the following way: 'I do not understand why I am arrested for beating my own wife because I have paid lobolo for her, and she belongs to me' (Baloyi 2009a:128). This argument indicates how some men use lobolo as an excuse to beat and abuse their wives. The last phrase, 'she belongs to me', even makes the abusive intention clearer, because the wife is owned. The Sesotho saying Lebitla la mosadi kebohadi [the grave of the woman is within her inlaws] is interpreted by some men as implying that women must be willing to be beaten, because they are bound in marriage for life, even if the marriage threatens their life (Masenya 2005:10). Many African people understand this saying as meaning that a woman should persevere in her marriage and nothing should take her out of her marriage before death. The African view of this argument has some agreement with the biblical perspective which denounces divorce in Matthew 19. The difference comes in when the traditionalists use the same argument to oppress and abuse women. It must be understood that the belief was not meant to force women to stay with their abusive husbands. It is only in the context where love and respect for each other are part of the reasons for marrying each other that the issue of staying together until death, can be emphasised. Although some will argue that the only reason for divorce should be adultery, in line with Matthew 19, it can still be dangerous to force one to continue living in an abusive relationship. Some say that it is still a widely believed African tradition that the herds of cattle, goats and sheep that people pay as bride wealth for their wives, give men the right to own and beat their wives at will (Masukume 2012:1; Waruta \& Kinothi 2000:123). According to tradition, if a wife leaves her marriage or divorces her husband for whatever reason, she is bound to pay back the lobolo which is very difficult for women to do since most of them are housewives without any employment or formal education (Kameri-Mbote 2000:20). My opinion is that people who use lobolo as an argument, misunderstand the intentions of the practice, hence they unfairly misinterpret and abuse it. There are many men who beat their wives without having paid lobolo, whilst others who did paid lobolo do not beat or abuse their wives.

\section{The agony of singlehood}

Single or unmarried people, particularly women in the African context, are stigmatised and rejected to the extent that many of them are challenged to find a substitute father to serve as an appropriate role model for their children (Koons \& Anthony 1991:126). This argument indicates that the African culture exploits single or unmarried women to the extent that singlehood is not accepted as a normal way of life, hence many try to avoid it at all cost. Kameri-Mbote (2000:20) has the same argument about Kenya where a Kenyan woman would always be afraid to 'rock the marriage boat', and therefore accepts the beating. Baloyi (2010a:725) argues: 'Nothing positive is said about women who have broken marriages and being single is associated with being anti-social.' The 'anti-social' in this context refers to the fact that most single women would withdraw themselves from other people. Koons and Anthony (1991:115) agree with Collins (1988:320) in saying that ' $[l]$ owered self-esteem and inferiority may contribute to social withdrawal'. It has become a tradition that every woman is expected to get married and bear children. Basically, this view is in agreement with the 
Bible which teaches about the first marriage being initiated and blessed by God (Gn 1:28a) and the instruction to be 'fruitful and multiply' (Gn 1:28). The problem arises when the understanding of childbearing becomes a condition through which one can be accepted in society. Since God gave childbearing as a gift, it should also be understood that He did not give the same gift to all and that being childless should not be used to marginalise or reject women. Whilst some older single people may be suspected of witchcraft (Phaswana 2005:1), others are suspected of having no intimate feelings. Just like in the Virgin Islands, single people in Africa are culturally unacceptable (Dickerson 1995:90). It is said that studies about women in the Virgin Islands indicate that their divorce has had a negative effect on them personally as well as on their families since singleness is not culturally acceptable in their society (Baloyi 2010a:725). Since the stigma of singleness is known to African people, not many women prefer to remain single. They therefore submit to wife beating for the sake of remaining in the marriage. Many African women would want to remain in their marriage at all costs, regardless of the beating, for the sake of not being stigmatised by being unmarried. This notion is supported by what Dr Patricia Kameri-Mbote (2000:20) refers to when saying that most women in Kenya would stop reporting and even testifying against their violent husbands. To conclude this section, some women internalised being beaten, reasoning: 'We must appreciate our husbands because they gave us their name of being Mrs Somebody' (Phiri 2003:23).

\section{Beating as a corrective measure}

It has also been reported from traditional viewpoints that wrongdoing by a woman (wife in this context) must be corrected by beating her. The quote entitled 'part of growing up' says: 'Young women are taught by their elders to accept punishment from their husbands when they are disobedient. Even cooking a bad meal warrants a smack' (Fidgen 2009:1). Although this quotation comes from the Zambian context, it can still be argued that most traditional African societies practice it. This argument is supported by the view of Dr Michael Mawema in Zimbabwe who held a similar patriarchal understanding in arguing that there is nothing wrong if wife beating is used as a corrective measure. Here we have a medical doctor who claims that wife beating reduces divorce and blames women's movements for instigating Zimbabwean young women to leave their husbands after the first fight (Wasike \& Waruta 2000:184). The beating, as one man explains it, curtails bad behaviour in women and disciplines them to keep them in line with what is wanted by the man.

According to Phiri (2003:24), '[o]ne of the ordained students asked how he was going to discipline his wife if we say that beating wives is wrong'. This was a responsive question during a discussion with Kenyan theological students about domestic violence in Christian homes. This question also testifies to the fact that it is still widely believed by some Africans that wife beating as a corrective tool is not wrong. Phoofolo (2007) said:
Some reasons cited by the husbands for beating their wives, and their attitude to it revealed in their court testimonies, suggests unmistakably that they were acting within the contemporary ideology that constructed husbands as patriarchs with the power to discipline their wives as minors. They often used words like 'chastise, thrash, punish' etc. to restore household order. (p. 382)

It thus becomes clear that husbands treat their wives as equal to children.

\section{African sayings or idioms}

There are idioms and sayings from most indigenous groups which emphasise wife beating as a norm for African marriages. For instance, one Shangaan idiom says: Nsati wa le nhongeni a nga yingisi [a woman who is always beaten with a stick does not mind being beaten anymore] (Junod 1990:188). This expresses the idea that women sometimes 'get used' to the beating in the sense that they internalise it. This saying does not only violate women's human rights, but it undermines the biblical teachings which emphasise the important role of love between husband and wife. Ephesians 5:25, which commands husbands to love their wives just like Jesus loved the church, is a good counterargument which indicates that love can produce a happy marriage. Wife beating, in contrast, does not show any sign of love, because no one should enjoy beating the woman he loves. According to another saying, Vukati bya katinga [marriage roasts], it should be expected that marriage is difficult, and everyone who wants to get married must be prepared for the roasting (Junod 1990:180; Sibuyi 2011:31). This idiom is also articulated by Mabunda (2013:1) who argued the following in one of her poems: Ku katinga ka vukati swi tiva hi lava nga ndzeni ka byona [roasting of the marriage is known or felt by those in it]. These arguments indicate that the issue of roasting in marriage entails very difficult challenges, particularly on the part of women.

The English word for 'helper' (which is traditionally used to refer to a wife), used in Genesis 2:18, can also be translated as companion, assistant, adviser and partner (Hornby 1987:556557). That is why Baloyi (2001:19) argues that, although husband and wife were created differently, they were meant to complement each other. In the creation narrative, the phrase It is not good for a man to be alone indicates that a woman or wife was created to be a companion and not to be roasted or subjected to any kind of violence and abuse. The initial biblical goal of marriage was that of friendship and companionship instead of roasting either one of the parties.

There are other idioms relating women to snakes which make it easier for men to treat them in the same way as they would treat snakes. One of these idioms says: Ku teka nsati I ku hoxa nyoka exinkwameni [to marry is to put a snake in one's handbag] (Junod 1990:181). Traditionally, whenever one sees a snake, the next action is to get a stick to beat and kill it. With this in mind, the treatment of a wife might be more or less similar to that of a snake. The very same saying implies that, since a snake cannot be trusted, because it can bite unexpectedly, a woman can do likewise. This is also in contradiction with what the Bible teaches when it says: 'I will 
make a suitable helper for him' (Gn 2:18). According to the idiom above, a woman is different from a man. Matthews (1996:213) puts it correctly when arguing that the sameness that is shared between man and woman cannot be found elsewhere in creation, because, according to the Scriptures, the female was created 'like what is in front of him'. Equating the status of a woman to that of a snake is to undermine the important role of a woman in her marriage.

According to Maluleke and Nadar (2002:11), another saying relating to woman abuse is: Vukati va kandza hi mbilu [to be successful in marriage a woman must be patient and obedient]. These sayings and many others are sometimes internalised. If a woman is not treated according to the meanings of these sayings, it is being suspected that something has gone wrong with the couple. Normally the community and family members would suspect the woman of having cast a spell on the man. Without undermining the possibility of the challenges in a marriage, it is unfair to expect women to be the only ones to shoulder the challenges in their marriage, whilst nothing is said about men. In actual fact, the husband and wife, who are taught in the Bible to be united and to become one flesh (in Mt 19:5), should equally accept the burden of challenges in their marriage without shifting them onto one party only.

\section{Power in marriage situations}

The biblical teaching on the relationship between husband and wife as been laid out in Paul's letter to the Ephesians (Eph 5:22-32) must also be understood when discussing issues relating to power in the family. Baloyi's (2008:5) exegetical study on Ephesians 5:22-32 indicated that the Greek manuscripts did not have the verb submit in verse 22 , but rather in verse 21 . This means that submission, which is traditionally understood as 'domination', was not only expected from wives, but from both persons in the relationship. It is this misinterpretation and misunderstanding of the word submission which cause many traditional African husbands to think that they have abusing power over their wives. Ephesians 5:22-32deserve to be read in conjunction with 1 Peter 3:1 which indicates that women are as submissive as men to Christ. Therefore, the author is in full agreement with Wiersbe (2002:76-77) and Gundry (1977:72) who clearly indicate that Ephesians 5:22-32 do not in any way intend to subordinate or subject one as in a situation of bondage. Rather, their aim is to emphasise a loving submission which is expected from both husband and wife. It is very important to also note that in Ephesians 5:25, the Bible instructs husbands to love their wives, and this is against any form of domination.

The reader should also understand that power need not be abusive. I agree with Pobee (1979) when he is arguing:

Power is a delicate thing which has to be handled with great care. Power is like an egg. If it is not handled with care, it destroys both the wielder and those over who it is wielded. (p. 147)

To make this clearer, we need to use the example given by Fowler (1991:4) about the fact that the intervention of both
America and Iraq in the Kuwait war was a result of the misuse of power. Only when power is abused or misused it becomes a bad thing. One of the biblical examples of the misuse of power is found in 1 Kings 21:1-16 where the king used his power to take Naboth's land. The judgment of God pronounced towards Ahab in 1 Kings 21:19 indicates clearly that God hates abuse and punishes those who abuse power. Alongside this passage, Ezekiel 22:6 and other related passages indicate God's anger towards those who abuse their power to subject and oppress others. The abuse of power can also be observed in the African way of life when some men want to be followed unconditionally.

Baloyi (2009a:154) articulates the point that, in the African context, the male who is also the source of income, is automatically given all the power to take final decisions in all matters. In the process, he will resort to force wife beating, for our purposes, to defend such power. Without denying the fact that the Bible teaches that a husband must ensure that he works hard in order to take care of his family as well as to supply their needs (Gn 3:17), we need to acknowledge that this was not intended to make him a dictator who will unconditionally dominate his wife. White (1988:121) believes that power can also be used wrongly when saying: 'The greater the power, the greater the danger.' This view receives support from Shaw (1983:204) who views power used to destroy or disadvantage others as ungodly. The patriarchal tradition allows men to take control and gives them more power than women. Therefore, in some cases, a husband would come home late at night and try to remove his wife from the bedroom and if she resists, he will start beating her (Baloyi 2009b:143; Sibuyi 2011:81; Mabunda 2013:2).

\section{Economic dependency}

I strongly agree with Waruta and Kinoti particularly in the context of the more traditional marriage in rural settings where women are less educated and many are unemployed, when they say:

Many women remain in abusive relationships because they have nowhere to go. Many women are economically totally dependent on their husbands, leaving marriage for them would mean living in poverty with no shelter and security. (Waruta \& Kinoti 2000:125)

Patriarchy was systematised in such a way that a woman was not to be educated nor employed so that she would take care of the household.

It is widely known that the financial or economic dependence of women on men as their husbands is the biggest problem faced by women in many communities. In an African community, an unemployed woman who has two or three children will be dependent on her husband for the sake of him supporting the children even when he is violent towards her. When the South African government introduced financial assistance in the form of social grants for children between particular ages, many citizens thought that this would also give some measure of support to the many uneducated and unemployed women. This grant is, however, for the child's 
early years only. In contrast, for the same economic reasons, some wives who earn more money than the husbands also become the targets of beating. According to Dreyer (2009), during one of his interviews on domestic violence, one woman said:

The jealousy started when I was earning more money than him. He took all my salary and never shared his salary with me. He would use all the money for drinking and whenever he came home from work drunk he would ask me for food and money. Whenever I refused he would beat me. I used to sleep outside to hide. (p. 14)

It is very clear that, in this instance, the fight usually occurs for economic reasons, and the beating is intended to obtain money from the wife.

\section{Alcohol and drug abuse}

One member of the Apostolic Church of Christ in Pietermaritzburg confirmed that her trouble started only after her husband had drunk alcohol: 'When he drinks alcohol, he shouts at me. He does not give me a chance to explain' (Phiri 2003:23). The abuse of alcohol and other substances form part of the problem as far as wife beating is concerned. Alsdurf (1989:82) quotes one recovering drug addict whose family was broken up as a result of his drug abuse: 'Drinking was like pouring gasoline on smouldering coals.' Braathen (2008:20) also testified to the same effect from a Malawian context, saying that most husbands become violent and irrational when they drink despite of the fact that women do their best to be good wives. The influence of alcohol and other related drugs has left many families broken. It becomes easier for men to claim that they know nothing about the fight that took place whilst they were drunk. This makes it easier for them to continue the beatings right after they had their next drink. It is true that most men, when drunk, cannot control their temper, and they beat and mistreat their wives without any apparent provocation (Baloyi 2009a:142; Bowman 2003:489; Kantor 1989:174).

\section{Childlessness or infertility}

The following quote is documented by Chigudu in research amongst the Shona-speaking people of Zimbabwe. It serves to indicate that the inability to conceive a child is also used as an excuse for wife beating amongst African people:

Georgia's husband battered her for eleven years because they couldn't have children. Her father-in-law finally threw her out because she had 'disgraced her family'. Being unable to have children is considered a crime. (Chigudu 2004:107)

Waruta and Kinoti (2000) argue as follows:

Amongst other factors that may cause wife beating are: financial stress and misunderstanding - in cases where the man seeks to control all the family budget - even the wife's personal salary, unfaithfulness between the husband and wife; barrenness and wife's refusal to submit to her husband. (p. 129)

The reader needs to acknowledge that, apart from some other reasons mentioned above, barrenness is one of the causes of women being beaten by their husbands (Sophanna 2006:88; Waruta \& Kinothi 2000:129). Phoofolo (2007:381), in his research amongst the Basotho people, supports this argument, documenting the following statement made by a man whilst beating his wife: 'All that comes out of your vagina is nothing but blood.' The African community traditionally believes that a lack of children in the family is always a woman's problem whilst men are exempted of any responsibility. That is why Mugambi (1989) said:

Procreation was very important in the African concept of marriage. A marriage in which children were not born was considered to be problematic, and sometimes the bride might be returned to her parents for such a reason. (p. 100)

The fact that the bride was returned, indicates clearly that it has always been the woman (not the man) who was regarded as having a problem. Mbiti (1991:133) also articulated that a childless marriage in the African context had little chance of survival. Although Mbiti's argument is linked to the socioeconomic situation of the olden days, it is still a problem for many African people to accommodate childless couples (Baloyi 2009b). The end of such marriages is usually ushered in by wife beating since the African tradition holds the view that the woman is always suspect whenever barrenness is perceived, even without medical investigation. Since ' $[b] \mathrm{e}$ getting children guaranteed eternal life', Turaki (1999:106) states that the one who was suspected of being barren in the family was treated as badly as possible. This is why women in particular were, and sometimes still are, the objects of such violence, beating included.

Childless marriages in the African context are considered abnormal and women usually become targets of blame for this abnormality (Baloyi 2009b:2) This kind of view is indeed contrary to the biblical teaching about marriage and barrenness. For instance, the Bible teaches that Hannah was remembered and favoured by both her husband and God regardless of her barrenness (1 Sm 1:1-12). It must also be remembered regarding the birth of Samuel that God is the Giver of children, hence there is no reason to blame either the husband or the wife for not bearing children. Instead of fighting over the absence of children, the couple should be encouraged to pray and wait on God who gives at his own will. It can also be argued biblically that a woman's worth has nothing to do with her childbearing, because Jesus Christ accepted women as part of his ministry on account of their faith. The fact that human beings (both sexes) are created in the image of God is a correct directive to accept that every person's worth cannot depend on any gift such as childbearing (Berkhof 1988:203; Borreson 1986:28). I wish to close this section with Galatians 4:27 and Isaiah 54:1 which says:

Rejoice o barren one who does not bear, break forth and cry aloud, you who are not in labor. For the children of the desolate one will be more than those of the one who has a husband.

\section{Sexual reasons}

Lopez (1979) says the following:

Women are sex. A man wants what a woman has - sex. He can steal it (rape), persuade her to give it away (seduction), rent it (prostitution), lease it over a long term (marriage), or own it outright (marriage in most African communities). (p. 176) 
'Lease it over a long term' is an example of forceful sexual intercourse within the confines of marriage. This negative view of sex makes women vulnerable to many forms of abuse by their husbands, beating included. The response of one of the interviewees by Dreyer (2009) in his research entitled Holistic pastoral ministry and the challenge of violence against women is as follows:

He forced me to have sex with him. If I said I was tired he forced me or beat me and said he paid lobola for me. I must give him anything that he wants. He said he married me for sex. So I have to do what he wants just to make him happy. (p. 15)

From another Zimbabwean newspaper article in which the author remained unknown, it was reported that one man left the Zimbabwean court in stitches after revealing that he bashed his wife, because she refused to have sex with him and he said: 'I beat her very hard because I wanted her to scream so that her aunt [who was sleeping in the next room] would know that I am being deprived of my conjugal rights.' (Anon 2013)

For many South Africans it was only after the dawn of democracy that they became aware of their rights when it comes to sexual matters. To some, however, the tradition is still that a woman does not have any rights regarding sexual matters, except to please the man (Baloyi 2010c:1). Sexual matters in this context had been understood as the domain where man should stamp his authority (Dreyer 2009:2).

Some women internalised the beating, because traditionally, they regarded it as both inhuman and disrespectful for a woman to report her own husband (Braathen 2008:20). That is why in explaining the biased traditional interpretation of Ephesians 5:23-24 by some traditionalists, Masenya (2005:188) says: 'The second text is usually cited to remind women that they must always be available for the sexual gratification of their spouses.' Besides the fact that women are expected to do much hard work in the family, she simultaneously also needs to be available at all times to satisfy her husband's sexual desires (Rakoma in Masenya 2005). Traditionally, there is no other reason, except when the woman is nursing a small baby or when menstruating, that would exempt her from sexual intercourse whenever the husband needs it. It must be understood that this is a traditional view held by some men, but not the intended meaning of Paul's letter.

\section{How wife beating is a challenge}

Many women chose to stay and sweep the battering under the carpet owing to the many other factors. In instances a woman may refuse to testify against her husband in criminal proceedings, which renders the prosecution's case unprovable. Some factors leading to not testifying include church teachings of the husband and wife being one. (Kameri-Mbote 2000:20)

This quotation flowing from the work of Kameri-Mbote (2000) amongst Kenyan people serves to indicate how difficult it is for certain ministers and pastoral caregivers in Kenya to intervene in times of wife beating. The biased teaching by the church is one of the reasons why it becomes so difficult for pastors to deal with issues of women abuse appropriately, because they would, in a sense, be against the very same teaching. To correct this, pastors need to start with the correct biblical interpretation of the misinterpreted sections of the Scripture in this context. These pastors should start by applying the correct interpretation whilst trying to convince women that it is within their rights to report these cases and also to stand firm in the courts of law against perpetrators. It will be important for pastors to indicate the unbiblical character, the consequences and the after effects of wife beating. If it is possible for the pastor to talk to husbands, it is important for the pastor to teach and encourage these husbands to love their wives as the Bible commands. From the above argument about the teaching of the church, it becomes clear that pastoral caregivers find it as much of a challenge to deal with issues of wife beating.

It is not always easy for pastoral caregivers to intervene, particularly when the pastor is a male, because he will most certainly be accused of having an affair with the beaten wife which is why he supposedly fights for her. I remember at least two pastors who have already been labelled in such manner. This now prevents them from trying to resolve such situations.

Secondly, the individualistic way of living, in contrast to communalism which Africans used to enjoy, makes it difficult to avoid problems related to wife beating. The South African government is making efforts through institutions such as the Gender Commission (Gabara 2012:1) to eliminate the abuse of women. These include awareness programmes that could take the form of road shows or indabas. African people should learn from the problem of wife beating that the earlier traditions, which expected people to live in community with each other, were not only important in the past, but are still important today. It is still important despite of the fact that to some, it poses a challenge, because many people have moved into urban areas. The pastoral advice, however, should be that African people need to realise that they are who they are because of others. The issue is that, in African tradition, the elders of the village used to call the husband to order whenever he would beat his wife. This practice has become very difficult to sustain now, because everyone lives in isolation from others. If someone happens to come to the rescue, it might be alleged that this person is interfering. People have abandoned the custom of calling the elders, either because of the Western influence or because they have moved to the townships. Couples have left the elderly behind and are left without a replacement of elderly responsibility which used to ensure that newly married people are guided to handle their differences and challenges. People now resort to court interdicts when they fail to resolve even very minor issues in their family.

Children are raised in difficult environments where they become daily witnesses of parental fights. Waruta and Kinoti (2000:130) say that children are also directly beaten in domestic violence or indirectly affected when watching their mother being beaten. This could easily lead to them becoming hostile towards the opposite sex and even hating the 
institution of marriage itself when they grow up. According to Hunt (2008:30), many learners who come from a family where parents abuse one another, do not become active participants at school and even drop out. The implication is that our country will continue to have illiteracy problems in future. In some cases, children may beat up the father or even kill him in trying to protect their abused mother. Children who have grown up in a violent family often display nervousness and withdrawal, anxiety, bed wetting, restlessness, low school performance and illnesses such as headaches, stomach complaints, asthma and stuttering. They also tend to be cruel to animals, copy aggressive language and behaviour in their play, run away from home and beat their girlfriends when they date as teenage boys (Waruta \& Kinoti ibid:131). Wife beating will certainly breed hostile children. These children who grow up seeing their mothers beaten, might copy this violent behaviour in their own role as husband or wife when they grow up (Osofsky 1999:36). That is what Cahn and Lloyd (1996:13) mean when they say: 'Moreover, abused children may as adults become abusers.' These will be the results of emotional as well as physical abuse instilled in them whilst watching the beating of their mother. Hostile behaviour by parents will, in all probability, breed hostile behaviour in future partners and parents.

It is advisable to immediately address these abusive tendencies and practices before entering into marriage if it rears its head whilst people are still courting (Baloyi 2001:25-26).

The traditional view of sexual intercourse as discussed above, makes it difficult from a pastoral point of view to eliminate sexually transmitted diseases such as HIV and AIDS (Kimani 2007:2). If it becomes a taboo (coupled with beating) for a woman to deny her husband unprotected sex, because the tradition says so, innocent women whose husbands are sleeping around with concubines and prostitutes are vulnerable to HIV and AIDS. Such parents extend the problem to children who might be orphaned by this traditional negligence (Barnett \& Blainkie 1992:1; Browder 2013:1).

\section{Possible guidelines and way forward The church as a healing community}

It is primarily the duty of the church to do everything in its power to set energies free for healing and rehabilitation by supporting those who are calling for law reform. The Bible lists many verses which teach about love, joy and patience, particularly in the marriage context. The fact that marriage was intended for companionship and help (Gn 2:18) indicates that wife beating was not part of the intention at all. The church must organise workshops, conferences and seminars where couples are taught and encouraged from the Bible to live in peace and love. The importance of prayer for the change of this traditional wrong, must form part of the teaching so that people may also know that the source of peace and love is God ( $\mathrm{Rm} 15: 13)$. The church, through its programs, can make use of seminars and conferences to invite gender activists to encourage the abused and abuser and create awareness of the dangers of wife beating.

The church has to provide professional counsellors who will endeavour to direct the abused and the abuser towards Christ and his reign of love and peace. Battered women need a Christian counsellor's affirmation that they are not to blame. Waruta and Kinoti (2000:132) are correct in saying that the church, as a healing community, should reach out to battered women, their children and their abusive husbands. It should bring God's compassionate and healing presence to such families. Since it is the church that knows very well that every human being is the image of God (women included), it should be the church that fights for the elimination of this scourge through its prophetic voice to the nation. Wimberly (1994) contends:

Women must be helped to overcome that they have no control over their being abused. They must also be helped to accept and understand that they are not responsible for the battering or any form of abuse. (p. 65)

It will also be better for the churches to establish centres of healing where the affected people can take refuge whilst being helped to search for meaning in their lives. In this way, the church will accept that it is part of the solution to the problem faced by battered women. Klein (2009:12) invites every local church to become a centre of healing and transformation through these holistic counselling services. This is an opportunity for churches to start moving towards the creation of these centres of healing.

\section{The government and its role through law and the courts}

The first point in this regard is to argue that, although wife beating is prevalent in many African countries because of cultural and traditional convictions, the following statement from the constitution, Article 9(4), should be applied to contexts where women are abused and battered: 'No person may unfairly discriminate directly or indirectly against anyone on one or more grounds' (Republic of South Africa 1996:7). It is therefore the responsibility of the government through its judiciary system to ensure that, for reported cases of wife beating, justice is done whilst also encouraging women to come out and report such incidents.

It is the author's contention that, if the law gave very harsh sentences to husbands who beat their wives, the rate of wife beating in our country would decrease considerably or even be eliminated completely. The escalation of this type of violence on its own is a testimony that culprits are not at all threatened by the law. According to Waruta and Kinoti (2000:134), even though there is no specific law against wife beating in Kenya, it is considered an offence under the penal code which states that it is an assault to an individual. The church, through its prophetic voice, should also advocate that government impose stiffer penalties for gender-related violence and make these cases a priority. 


\section{Women support groups}

Having support groups for affected women is neither intended to take the responsibility away from stakeholders who should play a role in this challenge nor to shift the burden of caring to somebody else. It is intended to rebuild the confidence of battered women and to show them that they carry some responsibility to liberate themselves too. The church and government will play their part whilst the victims should do the same. Victims need pastoral caregivers to encourage them to form support groups in which they will share their experiences and shape the way forward. Healing as well as rehabilitation may come as a result of sharing, praying together and encouraging together (Waruta \& Kinoti 2000:135). It is within these groups that victims can be educated to reject humiliation, ridicule, physical and psychological embarrassment. Pastoral caregivers can use these groups to bring awareness and to educate those women who are still held hostage by the tradition of trying to internalise and normalise wife beating. There are many unreported cases of wife beating, because women were traditionally told that such things need not be told or exposed since they belong to the family and the clan.

\section{Separation or divorce}

It is true that God has hated divorce right from the beginning of the institution of marriage. That is why the Bible says: 'What therefore God hath joined together, let no man put asunder' (Mt. 19:6; KJV). However, there are undoubtedly situations where one partner becomes hostile to the other to the extent that separation or divorce becomes a healthier solution for both. Before they separate or divorce, however, it would be good for them to first consult with counselling bodies such as FAMSA and other marriage counsellors who may be able to assist them. The author agrees with Waruta and Kinoti (2000:133) who contend that, in an abusive relationship, separation may in some instances lead to healing in both the abused and the abuser. Whilst it is the church's mission to proclaim the Good News, it should also be noted that it is from the very Good News that healing love and diakonia (as in Rm 15:31) should emerge. Without taking anything from the fact that the church's mission of salvation is to promote and foster healthy and healing human relationships at public and family level, it should also fight the challenges posed by abuse, exploitation and irresponsibility.

Traditionally, some parents are not comfortable when their daughters intend to divorce or separate, because they (the parents) cannot bear the traditional taboos associated with singleness, hence they insist that their daughters remain in their harmful marriages. For instance, one woman whose daughter was being abused by her husband brutally, allegedly said that she cannot stand the idea that her daughter should be divorced and become single in the community (Dreyer 2009:3). Pastoral caregivers also need to search for ways in which the community can deal with the beliefs and taboos created by the pressure of tradition and so protect the lives and health of individuals who are suffering under this scourge. Such parents and in-laws also need pastoral intervention which may help open their minds to see things differently.

\section{The Commission on Gender should intervene}

Pastoral caregivers also need to consider supporting and cooperating with the Commission on Gender in its efforts towards eliminating cruelty against women. Cooperation between pastoral caregivers and the Commission on Gender can be of crucial importance, particularly to help silent women to be vocal about their abuse. This kind of working relationship with religious leaders was also emphasised by the commission in its strategic plan (Commission for Gender Equality 2008-2013:51). It is the very same cooperation which may help in mobilising and bringing awareness to people about forms of abuse and encouraging them to stop abusive practices. This can be done by means of activities like road shows, seminars and other traditional gatherings. In fact, the combination of pastoral caregivers and the Commission on Gender should become the voice of the voiceless. It had been Cone's advocacy to make sure that pastors should be the voice of the voiceless in whatever circumstances (Cone 1975:63).

\section{Conclusion}

It is evident from the article that wife beating has not only become customary, but has also been internalised amongst some South African men. According to the research, the literature indicates that some traditions and sayings (idioms) indeed play a role in supporting the subjection and even beating of women by their husbands. It is also true that wife beating does not only humiliate women, but it is also a violation of the human rights which our country advocates. For this and other reasons mentioned, it has become very important to emphasise that it is the calling and the role of the church through its pastoral caregivers to undo the wrongs that were perpetrated by seeking ways to liberate women from this type of oppression. Even though various traditional reasons are used to argue in favour of wife beating, the truth logically remains that people need to understand that women's rights are also human rights (Baloyi 2010c:62). Pastoral caregivers and the law should ensure that perpetrators of wife beating are brought to book. Pastoral help should be given to avoid such practices at all cost. A tradition will always receive criticism if it attempts to be abusive. African scholars also need to ensure that the good traditions are guarded against those who use them to promote abuse or oppression of any kind.

\section{Acknowledgements Competing interests}

The author declares that he has no financial or personal relationship(s) which may have inappropriately influenced him in writing this article.

\section{References}

Alsdurf, F.P., 1989, Battered into submission, Intervarsity Press, Canada. 
Anon, 2007, 'Where am I wrong when I beat my wife', City Press, 18 February, p. 10.

Anon, 2013, 'Woman heavily beaten for refusing to have sex with hubby', in My Zimbabwe, viewed 14 August 2013, from www.myzimbabwe.co.zw/news/5741 woman-heavily-beaten-for-refusing-to-have-sex-with-hubby.html

Baloyi, M.E., 2001, Counseling Christian Shangaans on choosing a marriage partner, MA dissertation, Department of Practical Theology, University of Potchefstroom.

Baloyi, M.E., 2008, 'The Biblical exegesis of headship: A challenge to patriarchal understanding that impinges on women's rights in the church and society', Verbum et ecclesia 29(1), 1-13. http://dx.doi.org/10.4102/ve.v29i1.1

Baloyi, M.E., 2009a, Patriarchal structures: A hindrance to women's rights, VDM, Saarbrucken. PMid:19597877 PMCid:PMC3290404

Baloyi, M.E., 2009b, 'Critical reflections on infertility in Black Africa Christian communities', Journal of Practical theology in South Africa 24(2), 1-17.

Baloyi, M.E., 2010a, 'Pastoral care and the agony of singleness in the African Christian context', In die Skriflig 44(3/4), 723-741.

Baloyi, M.E., 2010b, 'Lobolo in the African community', Journal of Theology and Religion in Africa 34(1), 50-70.

Baloyi, M.E., 2010c, 'An African view of women as sexual objects as a concern for gender equality: A critical study', Verbum et Ecclesia 31(10), 1-6.

Barnett, T. \& Blaikie, P., 1992, Aids in Africa: Its present and future impact, Guildford Press, New York. PMid:20305105, PMCid:PMC3290406

Berkhof, L., 1988, Systematic theology, Zondervan, Grand Rapids, MI.

Borreson, K.E., 1986, Subordination and equivalence: The nature and role of women in Augustine and Thomas Aquinas, Kok Pharoas Publishing House, Kampen.

Bila, N.J., 2003, Unpublished speech on the road show held at Mukhomi outside Malamulele in Limpopo.

Bowman, C.G., 2003, Domestic violence: Does the African context demand a different approach?, Cornell Law Library, Chicago.

Braathen, A.H., 2008, 'Substance use and gender-based violence in Malawian context: Pilot Project 2', in Sintef Health Research, viewed 12 July 2013, from www.sintef.

Browder, S.E., 2013, 'Dirty little secret: Why condoms will never stop Aids in Africa', in Holy Spirit Interactive, viewed 12 July 2013, from www.holyspiritinteractive.net

Burkhart, J.E., 1983, Schleiermarcher's vision for theology in practical theology, Harper and Row, San Francisco.

Cahn, D.D. \& Lloyd, S.A., 1996, Family violence from a communication perspective, Sage Publications, New Delhi.

Chigudu, H. (ed.), 2004, Composing a new song: Stories of empowerment from Africa, Weaver Press, Harare.

Collins, G.R., 1988, Christian counselling, Word Publishing, Dallas.

Commission for Gender Equality, 2008-2013, A society free from gender and equality: A strategic plan, viewed 10 September 2013, from www.info.gov.za

Cone, J.H., 1975, God of the oppressed, Seabury Press, New York.

Cone, J.H., 1986, A black theology of liberation, Orbis Books, New York.

Day, S., 2013, South African women mobilize against domestic abuse, viewed 09 July 2013, from http://journalism.berkeley.edu/projects/southafrica/news/ abuseprinterfriendly.htm

Deegan, H., 2009, Africa today: Culture, economics, security, Routledge, New York.

Dickerson, B.J., 1995, African American single mothers: Understanding their lives and families, Sage, New Delhi.

Dreyer, J.S., 2009, 'Holistic pastoral ministry and the challenge of violence against women', paper read at the Joint Conference of Academic Societies in the Fields of Religion and Theology, University of Stellenbosch, 25 June.

Fidgen, J., 2009, Zambia's celebrity couple reveal wife-beating past, viewed 09 July 2013, from http://news.bbc.co.uk/2/hi/africa/8375291.stm

Fowler, S., 1991, The deceptive morality of power, IRS, Potchefstroom.

Gabara, N., 2012, National body to tackle gender violence, viewed 13 September 2013, from www.southafricainfo/services/rights/gender

Gerkin, C., 1997, An introduction to pastoral care, Abingdon Press, Nashville.

Gundry, P., 1977, Women be free: Biblical equality for men, Suitcase Books, Grand Rapids, MI

Hinga, T.M., Kubai, A.N., Mwaura, P. \& Ayanga, H., 2008, Women religion and HIV/AIDS in Africa. Responding to Ethical and theological challenges, Cluster Publications, Pietermaritzburg.
Hornby, A.S. (ed.), 1987, Oxford advanced leaner's dictionary of current English, University Press, Oxford.

Hunt, F., 2008, Dropping out from School: A cross country review of literature Create pathways to access research, Monograph no. 16, Centre for International Education, University of Sussex.

Junod, H.P., 1990, The wisdom of Tsonga, Sasavona Publishers, Braamfontein.

Kameri-Mbote, P., 2000, Violence against women in Kenya: An analysis of law, policy and institutions, in International Environmental Law Research Centre, viewed 12 July 2013, from www.ielrc.org/content/w0001.pdf

Kimani, M., 2007, 'Taking on violence against women in Africa', in International World Health Organization, viewed 12 July 2013, from www.un-org/afircarenewal. magazine/july-2007

Kantor, K.G., 1989, 'Substance abuse as a precipitant of wife abuse victimizations', PhD thesis, Dept. of Psychiatry, University of New Hampshire.

Klein, H.L., 2009, Centres of healing, AcadSA, Kempton Park.

Koons, C. \& Anthony, M., 1991, Single adult passages: Uncharted stories, Baker, Grand Rapids. PMCid:PMC1793040

Lopez, E.H., 1979, Eros and ethos, Prentice Hall, Englewood Cliffs.

Mabunda, N.P., 2013, Vut/hari bya manguva lawa, viewed 14 August 2013, from www.matimunews.co.za

Maluleke, T.S. \& Nadar, S., 2002, 'Breaking the covenant of violence against women', Journal of Theology for Southern Africa November, 5-7.

Masenya (ngwan'aMphahlele), M., 2005, 'The Bible, HIV/AIDS and AfricanSouth African women: A Bosadi (womanhood) perspective', Studia Historiae Ecclesiasticae 31(1), 187-201.

Masukume, N., 2012, Lobola linked to domestic violence in Zimbabwe, viewed 09 July 2013, from www.zimdiaspors.com

Matthews, K.A., 1996, The New American commentary, vol. 1, Library of Congress, Broadman and Hollman, Michigan.

Mbiti, J.S., 1991, Introduction to African Religion, 2nd edn., Heinemann, Sandton.

Mugambi, J.N.K., 1989, African heritage and contemporary Christianity, Longman, Nairobi.

Osofsky, J.D., 1999, 'The impact of violence on children', The future of children: Domestic violence and children 9(3), 39-49.

Phaswana, D.R., 2005, 'Counseling singles', paper read at a meeting of reformed pastors, 06 March 2005, Sibasa.

Phiri, I.A., 2003, 'Why does God allow our husbands to hurt us: Overcoming violence against women', Journal of Theology for Southern Africa November, 19-30.

Phoofolo, P., 2007, 'Holy weddings, unholy marriages: Christian spouses and domestic discords in early colonial Lesotho, 1870-1900', Journal of religious History 31(4), 363-386. http://dx.doi.org/10.1111/j.1467-9809.2007.00688.x

Pobee, J.S., 1979, Towards an African theology, Abingdon Press, Nashville. PMCid:PMC2395756

Rampedi, P., 2010, 'Woman killed for going on the pill', City Press, 24 January, p. 8.

Shaw, G., 1983, The cost of authority. Manipulation and freedom in the New Testament, SCM Press, London.

Sibuyi, E.M., 2011, 'The analysis of the impact of non-verbal communication in Xitsonga discourse', MA dissertation, African Languages and communication department, University of Limpopo.

Sophanna, S., 2006, 'Gender, culture and infertility in Cambodian society subjects', PhD thesis, Dept. of Health and Social Science, Mahidol University.

Republic of South Africa, 1996, Constitution of the Republic of South Africa, Act 108 of 1996, 11 Oct, Ch. 2, p. 7, Government Printer, Pretoria.

Turaki, Y., 1999, Christianity and African gods: A method in theology, Scholarly contributions of PU for CHE, Institute for Reformational Studies, Potchefstroom. (Series F2, no. 75)

Waruta, D.W. \& Kinoti, H.K., 2000, Pastoral care in African Christianity, Acton Press, Nairobi.

Wasike, A. \& Waruta, D.W. (eds.), 2000, Mission in African Christianity: Critical Essays in Missiology, Acton Publishers, Nairobi.

White, J., 1988, When the spirit comes with power signs and wonders amongst God's people, Intervarsity Press, Illinois.

Wiersbe, W.W., 2002, Caring people: Learning to live with and help one another, Baker, Grand Rapids.

Wimberly, E.P., 1994, Using Scripture in pastoral counseling, Abingdon Press, Nashville. 